\title{
NARZĘDZIA RACHUNKOWOŚCI ZARZĄDCZEJ A POKONYWANIE TRUDNOŚCI W PROCESIE ROZWOJU MAŁEJ FIRMY
}

\begin{abstract}
Małe i średnie przedsiębiorstwa odgrywają znaczącą rolę w rozwoju gospodarczym. Ta grupa przedsiębiorstw odróżnia się od innych podmiotów specyficznymi cechami, m.in. sposobem zarządzania. Wiedza właścicieli - przedsiębiorców z zakresu kierowania przedsiębiorstwem w przypadku zwłaszcza małych przedsiębiorstw, jest często niewystarczająca, a decyzje są niejednokrotnie podejmowane intuicyjnie. Ważnym problemem są przeszkody tkwiące w działaniach właścicieli firm, związane z ich postawą. Przyjmowane przez nich rozwiązania dla zapewnienia doraźnego sukcesu lub w dłuższej perspektywie stabilności firmy - podejmowane są spontanicznie - na zasadzie wykorzystania pojawiających się szans. Należy jednak pamiętać, że rodzaj, wielkość i zakres trudności w funkcjonowaniu małych i średnich przedsiębiorstw - są uzależnione od wielu czynników, w tym również od wieku przedsiębiorstwa. Charakterystyczny dla funkcjonowania tych firm, jest proces wzrostu, przechodzenia w kolejne fazy rozwojowe, poprzedzone kryzysami. W poszczególnych etapach życia małego przedsiębiorstwa pojawiają się nowe wyzwania, które wymagają trafnych decyzji, podjęcia ryzyka i pokonywania trudności. Stąd ważne wydaje się właściwe dobranie instrumentów, które będą pomagały w ich pokonaniu. W artykule, na tle popularnych modeli wzrostu przedsiębiorstwa, analizie poddano bariery występujące w przełomowych momentach funkcjonowania małej i średniej firmy i podjęto próbę ich usystematyzowania. Na tak zarysowanym tle przedstawiono wybrane narzędzia rachunkowości zarządczej, które mogą wspierać przedsiębiorców w niwelowaniu negatywnych skutków kryzysów, występujących pomiędzy kolejnymi fazami wzrostu przedsiębiorstwa.
\end{abstract}

Słowa kluczowe: małe i średnie przedsiębiorstwo, rachunkowość zarządcza, procesy rozwoju MSP, bariery rozwoju MSP.

\section{WPROWADZENIE}

Rola i znaczenie małych i średnich przedsiębiorstw w gospodarce wydają się niezaprzeczalne. Ta grupa przedsiębiorstw wydaje się również interesująca ze względu na specyficzne cechy i sposoby zarządzania, a także szczególny sposób wzrostu od małej - początkującej do dojrzałej organizacji. Na drodze rozwoju pojawiają się trudności, które mogą być sklasyfikowane jako te dotyczące bieżącej działalności lub momentów przełomowych wywołanych kryzysami. Celem niniejszego opracowania jest próba wskazania narzędzi rachunkowości zarządczej, które mogłyby wspierać pokonanie tychże barier przez małe

\footnotetext{
${ }^{1}$ Dr inż. Adriana Kaszuba-Perz, adiunkt w Zakładzie Finansów, Bankowości i Rachunkowości, Wydział Zarządzania Politechniki Rzeszowskiej im. I. Łukasiewicza, Al. Powstańców Warszawy 8, 35-959 Rzeszów; e-mail: aperz@prz.edu.pl.
} 
przedsiębiorstwa ${ }^{2}$. W artykule na tle popularnych modeli wzrostu przedsiębiorstwa, analizie poddano bariery występujące w przełomowych momentach funkcjonowania małej i średniej firmy i podjęto próbę ich usystematyzowania. W tym kontekście przedstawiono wybrane narzędzia rachunkowości zarządczej, które mogłyby przyczynić się do niwelowania negatywnych skutków kryzysów, występujących pomiędzy kolejnymi fazami wzrostu przedsiębiorstwa.

\section{ROLA MAŁYCH I ŚREDNICH PRZEDSIĘBIORSTW I SPECYFIKA ICH ZARZĄDZANIA}

Małe (lub jak częściej określa się w literaturze większą grupę: małe i średnie) przedsiębiorstwa zostały wyodrębnione spośród innych sektorów gospodarki ze względu na ich szczególny charakter, zarówno jeśli chodzi o rolę, jaką odgrywają w gospodarce, jak również ze względu na odmienność działania. Pozytywny wpływ sektora MSP na procesy rozwojowe gospodarki jest niezaprzeczalny. Wynika to $\mathrm{z}$ faktu, iż sektor ten wykazuje większą odporność na kryzysy, dzięki elastyczności w dostosowywaniu się do zmiennych warunków działania. Koszty technicznego uzbrojenia pracy, są zazwyczaj znacznie niższe w tym sektorze niż przeciętne w gospodarce. Małe i średnie przedsiębiorstwa wykorzystują często miejscowe surowce i zasoby pracy ludzkiej, rozpoczynają działalność w tych dziedzinach gdzie jest duży popyt lub istnieje relatywnie mniejsza konkurencja - często są to dziedziny niszowe. Dzięki temu wzrastają szanse ich rozwoju także w okresach niekorzystnej koniunktury. Ponadto należy podkreślić, iż drobni przedsiębiorcy pochodzą zazwyczaj ze środowiska lokalnego i rozwój ich przedsiębiorczości może stanowić ważny czynnik aktywizacji w regionie. Powyższe przesłanki wskazują na dużą rolę małych i średnich przedsiębiorstw w gospodarce Zagadnienia te porusza wielu naukowców ${ }^{3}$.

Według koncepcji K. Poznańskiej i M. Schulte-Zurchausen, kryteria klasyfikacji małych i średnich przedsiębiorstw i ich odmienność w porównaniu z działalnością dużych firm można charakteryzować w następujących zakresach: system zarządzania, organizacja, produkcja, badania i rozwój, gospodarka materiałowa i zaopatrzenie, finanse oraz kadry.

Różnice pomiędzy firmami należącymi do MSP i firmami dużymi w zakresie systemu zarządzania dotyczą m.in. funkcji kierowniczych. Funkcje te w przedsiębiorstwach dużych pełnią powołani przez właścicieli menadżerowie, natomiast $w$ tych mniejszych - właściciel występujący zazwyczaj w roli przedsiębiorcy i menedżera jednocześnie. Wiedza z zakresu kierowania przedsiębiorstwem w przypadku właściciela-menedżera jest często niewystarczająca, a decyzje są niejednokrotnie podejmowane intuicyjnie. W dużych zaś podmiotach cały system informacyjny jest głęboko rozbudowany i sformalizowany. Istotną rolę w zarządzaniu dużymi przedsiębiorstwami pełni planowanie, w przeciwieństwie do małych firm gdzie decyzje często podejmowane są spontanicznie - na zasadzie wykorzystania

\footnotetext{
${ }^{2} \mathrm{Z}$ uwagi na wielowątkowość i obszerność podjętej problematyki, w artykule przedstawiono tylko część zagadnień, które są jednocześnie przedmiotem aktualnie prowadzonych głębszych badań.

${ }^{3}$ Zob. m.in. P. Bober, S. Chęciński, Kryzys gospodarczy a rozwój sektora matych i średnich przedsiębiorstw w Polsce, Zeszyty Naukowe Uniwersytetu Szczecińskiego nr 690; Finanse, Rynki Finansowe, Ubezpieczenia nr 51/2012; M. Kochamńska, Bariery rozwoju przedsiębiorczości matych $i$ średnich firm, Zeszyty Naukowe 1, Sosnowiec 2007; A. Kaszuba-Perz, Warunki przezwyciężania barier rozwoju matych i średnich przedsiębiorstw w Polsce potudniowo-wschodniej, rozprawa doktorska - UEK, Kraków 2001, materiał niepublikowany.
} 
pojawiających się szans. Takie podejście nie zawsze sprawdza się w dłuższej perspektywie. Kolejną ważną cechą małych przedsiębiorstw jest autokratyczny system zarządzania, praktycznie nie występuje przekazywanie uprawnień kierowniczych. Z kolei pod względem organizacji małe i duże podmioty różnią się rodzajem struktury organizacyjnej, bowiem w przypadku tych pierwszych ma ona charakter funkcjonalny. Takie rozwiązanie ma swoje zalety: krótki i bezpośredni przepływ informacji, niski stopień sformalizowania oraz duża elastyczność.

\section{TRUDNOŚCI, BARIERY I KRYZYSY W PROCESIE WZROSTU MAŁEJ FIRMY}

Pod pojęciem trudności i barier rozwoju będą rozumiane siły, które uniemożliwiają wzrost organizacji lub jej ekspansję. Mogą one być rozpatrywane w sposób ogólny z punktu widzenia bieżącej działalności przedsiębiorstwa. Drugie zaś podejście jest powiązane z faktem zaistnienia tychże trudności w przełomowych momentach funkcjonowania przedsiębiorstwa. Stąd też poniżej zaprezentowano w pierwszej kolejności klasyfikacje barier występujących na drodze rozwoju małych i średnich przedsiębiorstw. Następnie przedstawiono dwa wybrane modele wzrostu przedsiębiorstwa, uwzględniające tzw. kryzysy - wywołujące zmianę ${ }^{4}$. Na podstawie analizy modeli wzrostu przedsiębiorstwa podjęto próbę określenia barier występujących w momentach przełomu.

M. Matejun zaproponował klasyfikację barier rozwoju małych i średnich przedsiębiorstw dzieląc je na dwie zasadnicze grupy: bariery wewnętrzne oraz bariery zewnętrzne ${ }^{5}$. $\mathrm{Na}$ bariery zewnętrzne składają się głównie: bariery rynkowe, informacji, w tym edukacyjne, infrastrukturalne, lecz również te, które mają charakter polityczny i prawny. Autor opisując bariery wewnętrzne podkreśla te, które dotyczą niedostatków w zakresie zarządzania, produkcji oraz wynikające $\mathrm{z}$ niewielkich rozmiarów działalności.

Dla sklasyfikowania barier rozwoju przedsiębiorstw można również przyjąć bardziej szczegółowe podejście, dzieląc je na: makroekonomiczne - w sferze regulacyjnej i realnej oraz mikroekonomiczne - w sferze regulacyjnej i realnej ${ }^{6}$. Wśród barier makroekonomicznych sfery regulacyjnej można wymienić m.in. niesprawności systemu podatkowego oraz polityki handlowej, zaś sfery realnej np. nierozwinięte mechanizmy transferu technologii. Do najważniejszych barier mikroekonomicznych w sferze regulacyjnej zalicza się: koszty pracy (w tym zwłaszcza, w kontekście nakładów na ubezpieczenia społeczne), ograniczone możliwości planowania wynikające głównie z chwiejności politycznej, natomiast w sferze realnej: głównie bariery finansowe, bariery inwestycyjne i bariery popytu, których źródłem jest duża konkurencja.

Inni badacze wymieniają wśród barier, które bywają przyczynami niepowodzeń firm m.in.: kłopoty finansowe, brak współpracy z otoczeniem przy jednoczesnych problemach

\footnotetext{
4 Typologia przyjęta w niniejszym opracowaniu na trudności bieżącej działalności oraz trudności występujące w sytuacjach kryzysowych -została dostosowana do postawionych celów. Pozwala bowiem w przejrzysty sposób zaprezentować propozycję wybranych narzędzi rachunkowości zarządczej możliwych do zastosowania w procesie pokonywania trudności.

${ }^{5}$ M. Matejun, Bariery rozwoju matych i średnich przedsiębiorstw (na podstawie badań w aglomeracji tódzkiej) [w:] Przedsiębiorczość szansa na sukces rzadu, gospodarki, przedsiębiorstw, spoteczeństwa, red. K. Piech, M. Kulikowski, Warszawa 2003.

${ }^{6}$ A. Kaszuba-Perz, Warunki przezwyciężania barier rozwoju...
} 
z komunikacją wewnętrzną i zewnętrzną, w tym również niechęć do korzystania z doradztwa zewnętrznego oraz przyjmowania krytycznych uwag ${ }^{7}$.

Kumulacja przeróżnych trudności powoduje zagrożenie funkcjonowania przedsiębiorstwa, które określa się mianem kryzysu, przy czym może on stać się przełomem pomiędzy dwoma fazami cyklu życia organizacji. Taką definicję podaje m.in. B. Wawrzyniak. Jak pisze dalej, zakres, czas trwania i zjawiska występujące w takim momencie mogą się różnić, a ich następstwem są mniej lub bardziej poważne skutki, przejawiające się np. rozwojem nowej sytuacji ${ }^{8}$. Proces wzrostu zaproponowany w przez klasyków, tj. N.C. Churchil'a oraz V.L. Levis'a9 - uwzględnia przełomy wywołane przez kryzysy. To właśnie te trudne momenty w życiu przedsiębiorstwa są zwrotnymi punktami, które powodują przejście w kolejny etap.

Niewątpliwie czynniki makroekonomiczne i mikroekonomiczne występujące w sferach regulacyjnej i realnej mocno wpływają na przebieg procesu wzrostu przedsiębiorstwa. Pierwsze trudności lub kryzys - przychodzący po powstaniu firmy może powodować wzmocnienie dążenia przedsiębiorcy do ustabilizowania sytuacji na rynku, co staje się głównym czynnikiem kształtującym strategię małego przedsiębiorstwa. Po etapie przetrwania, następuje kolejny punkt zwrotny, w którym przedsiębiorca-właściciel dąży najczęściej do osiągnięcia znaczących wyników (finansowych, rynkowych, innych) podejmując przy tym ryzykowne decyzje. Wyniki te mogłyby przyczynić się do zapewnienia przedsiębiorstwu rozpoznawalności lokalnej lub szerszej (w zależności od przyjętej skali działania i strategii). Kolejny przełom po trzecim etapie - sukcesu, często umożliwia zmiany struktury przedsiębiorstwa oraz potrzebę i chęć rozbudowywania (w tym również systemów informacyjnych przedsiębiorstwa). Wzrost firmy w czwartej fazie wzrostu przedsiębiorstwa to okres poszukiwań nowych rozwiązań zarówno w technologii, dystrybucji, nowych produktów, lecz również, obrębie zarządzania. Przełom występujący po etapie rozwoju a przed okresem dojrzałości - jest momentem w którym następuje swego rodzaju przesilenie. Po procesie dynamicznych zmian i wzrostu istnieje bowiem ryzyko stagnacji. Często kryzys ten jest powiązany z problemem sukcesji w przypadku firm rodzinnych, lub poszukiwaniem nowych możliwości działania poprzez debiut na rynkach kapitałowych (w przypadki małych i średnich przedsiębiorstw - New Conect). Istotnym zatem - zwłaszcza z punktu widzenia utrzymania długofalowego wzrostu przedsiębiorstwa -jest zbudowanie stabilności finansowej $\mathrm{i}$ wizerunkowej firmy.

Przydatnego, z punktu widzenia prowadzonych w niniejszym opracowaniu rozważań, przeglądu literatury (wraz z analizą definicji) dotyczącej zjawiska kryzysu w przedsiębiorstwie dokonały w swojej pracy M. Gorzelany-Dziadkowiec i E. Kozień ${ }^{10}$. Autorki podsumowując tenże przegląd zwróciły uwagę na fakt, iż kryzys stanowi pewną niestabilną sytuację mogącą wywołać zagrożenie osiągnięcia postawionych celów, stan niepewności, zakłócenia - mogące przesądzić o dalszym funkcjonowaniu przedsiębiorstwa.

7 R. Lisowska, J. Ropęga, Przyczyny upadku matych firm na terenach zmarginalizowanych [w:] Problemy ekonomii, polityki ekonomicznej i finansów publicznych, red. J. Sokołowski, Prace Naukowe Uniwersytetu Ekonomicznego we Wrocławiu, t. 1, nr 39/2009.

${ }^{8}$ B. Wawrzyniak B., Odnowienie przedsiębiorstwa. Na spotkanie XXI wieku, Warszawa 1999, s. 58.

9 N.C. Churchil, V.L. Levis, The five stages of small business growth, Harvard Business Review, May-June 1983.

${ }^{10}$ M. Gorzelany-Dziadkowiec, E. Kozień, Wptyw kryzysu na rozwój matego przedsiębiorstwa, Zeszyty Naukowe UEK, 2013/908. 
Ważnym modelem wzrostu organizacji jest model zaproponowany przez L.E. Grein$\mathrm{era}^{11}$. Został on w uproszczonej formie zaprezentowany na rys. 1. Proces rozwoju podmiotu został określony przez Greinera za pomocą wyodrębnienia wewnętrznych i zewnętrznych czynników wpływających na przedsiębiorstwo. Suma wybranych spośród nich, może stać się determinantą pojawiających się kryzysów, te zaś przyczyniają się do wejścia w kolejne etapy wzrostu przedsiębiorstwa. Kryzys bowiem może mieć wydźwięk negatywny jak i pozytywny. W przypadku tego drugiego staje się szansą implementacji nowatorskich rozwiązań, bądź podjęcia ryzykownych decyzji, co skutkuje poważną przemianą w „,historii” życia organizacji.

Faza 1 Wzrost przez kreatywność - kryzys przywództwa<smiles>C1CCCC1</smiles>

Faza 2 Wzrost przez formalizację - kryzys autonomii<smiles>CC1CCC1</smiles>

Faza 3 Wzrost przez delegowanie uprawnień - kryzys kontroli<smiles>C1CCCC1</smiles>

Faza 4 Wzrost przez koordynację - kryzys biurokracji

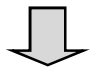

Faza 5 Wzrost przez współpracę - kryzys

Rys. 1. Kryzysy wywołujące wzrost organizacji według L.E. Greinera

Źródło: L.E. Greiner, Evolution and Revolution as Organizations Grow, „Harvard Business Review”, July-August 1972, s. 37-46.

Greiner, wśród czynników zewnętrznych, wymienia m.in. dynamikę rynku, czy strukturę sektora. Wśród badaczy tego zagadnienia pojawiają się również inne, m.in. ograniczenia polityczne i prawne, podatkowe itd. ${ }^{12}$ Poszukiwanie i zastosowanie rozwiązań (często innowacyjnych i/lub wysoce ryzykownych), pozwala przedsiębiorstwu na przekroczenie granicy, po której przechodzi ono w kolejną fazę rozwoju. Warto także zaznaczyć, iż nie zawsze kryzys zażegnany zostaje z pozytywnymi skutkami. Przy niesprzyjających warunkach lub źle zdiagnozowanej sytuacji i błędach w decyzjach, efektem takiego przełomowego momentu, może okazać się upadek firmy.

${ }^{11}$ L.E. Greiner, Evolution and Revolution as Organizations Grow, „Harvard Business Review”, JulyAugust 1972.

12 Zob. m.in. K.H. Vesper, Entrepreneurship and National Policy, Carnegie-Mellon University, The Graduate School of Industrial Administration, Pittsburgh 1983. 
Wskazane powyżej bariery o charakterze ogólnym oraz trudności wynikające z kryzysów pojawiających się pomiędzy kolejnymi fazami wzrostu przedsiębiorstwa, implikują potrzebę wsparcia procesów decyzyjnych w szczególnych momentach życia organizacji oraz w bieżącej jej działalności.

\section{ROLA WYBRANYCH NARZĘDZI RACHUNKOWOŚCI ZARZĄDCZEJ W POKONYWANIU TRUDNOŚCI PRZEDSIĘBIORSTWA}

Niewątpliwie istotnymi elementami w pokonywaniu wszelkich trudności w przedsiębiorstwie są: prawidłowa diagnoza sytuacji, bank sprawdzonych informacji oraz umiejętność analizy tychże, wraz z wyciąganiem trafnych wniosków. Jak próbowano wskazać powyżej, jedną ze specyficznych cech małych przedsiębiorstw, jest częste podejmowanie decyzji jednoosobowo, przez przedsiębiorcę - menadżera. Takie sytuacje zdarzają się często zwłaszcza w pierwszych fazach funkcjonowania organizacji. Właściciel pełniący funkcję menedżera popełnia często błędy w etapie uruchomienia firmy, z czasem one nawarstwiają się. Przekonanie o nieomylności oraz determinacja w realizacji wyznaczonych celów przy jednoczesnych niedostatkach wiedzy z zakresu zarządzania i finansów, bywa często przyczyną niepowodzeń i trudności. Zwłaszcza w pierwszych etapach funkcjonowania przedsiębiorstwa (kiedy zaliczana jest ona do grupy mikro lub małych), wewnętrzne i zewnętrzne czynniki wpływające na przyszłość lub bieżącą sytuację, a tym samym i kształt strategii, są często niedostrzegane lub niedoceniane przez przedsiębiorców. Zatem właściwa identyfikacja tych czynników, budowanie bazy informacyjnej - może być uważane wówczas za jedną z kluczowych aktywności, przyczyniających się do prawidłowego zarządzania firmą. W świetle przyjętego celu niniejszego opracowania i analizy przeprowadzonej w pkt 2, dla barier rozwoju małego i średniego przedsiębiorstwa przyjęto następującą ich typologię: makroekonomiczne - zewnętrzne oraz mikroekonomiczne - wewnętrzne (zob. tabela 1). Taki podział przeszkód wzrostu przedsiębiorstwa jest pomocny w zidentyfikowaniu możliwych do wykorzystania narzędzi rachunkowości zarządczej przydatnych w pokonywaniu tychże trudności i barier. Zastosowany podział jest próbą uporządkowania różnorodnych klasyfikacji stosowanych przez wielu ekonomistów zajmujących się analizą czynników i barier rozwoju przedsiębiorstw. Tak skonstruowany podział jest wynikiem analiz prowadzonych w ramach prac badawczych, na temat warunków przezwyciężania barier rozwoju małych i średnich przedsiębiorstw ${ }^{13}$.

\footnotetext{
${ }^{13}$ Badania naukowe przeprowadzone przez autorkę nt: Warunków przezwyciężania barier rozwoju małych i średnich przedsiębiorstw w Polsce Południowo-Wschodniej, (rozprawa doktorska: AE Kraków, 2001) były podstawą dokonania typologii barier na: makroekonomiczne i mikroekonomiczne, w sferze regulacyjnej i realnej. Dla zidentyfikowania tych barier przeprowadzono badania jakościowe wśród przedstawicieli MSP. W niniejszym opracowaniu - ze względu na obszerność i wielowątkowość podjętej tematyki, dokonano uproszczenia w postaci podziału barier wzrostu przedsiębiorstw jedynie na dwie grupy. Zaś biorąc pod uwagę zmienność otoczenia i warunków funkcjonowania MSP dzisiaj, badania są obecnie kontynuowane i rozszerzone o nowe zagadnienia. Niniejszy artykuł jest jedynie próbą sprecyzowania jednego z obszarów prowadzonego aktualnie procesu badawczego.
} 
Tabela 1. Wybrane narzędzia rachunkowości zarządczej wspomagające pokonanie barier w rozwoju małego i średniego przedsiębiorstwa

\begin{tabular}{|c|c|c|}
\hline Grupa barier & $\begin{array}{c}\text { Identyfikacja trudności } \\
\text { lub/i potrzeby informacyjne }\end{array}$ & $\begin{array}{c}\text { Wybrane narzędzia rachunkowości } \\
\text { zarządczej }\end{array}$ \\
\hline \multicolumn{3}{|c|}{ Bieżąca dziatalność przedsiębiorstwa } \\
\hline $\begin{array}{l}\text { Bariery makroekono- } \\
\text { miczne/ zewnętrzne }\end{array}$ & $\begin{array}{l}\text { Braki w dokładnej analizie } \\
\text { otoczenia i identyfikacji ryzyk } \\
\text { w nim występujących; nie sto- } \\
\text { sowanie technik analizy strate- } \\
\text { gicznej (dot. małych przedsię- } \\
\text { biorstw). W średnich przedsię- } \\
\text { biorstwach zaś chętnie wyko- } \\
\text { rzystywane są metody jako- } \\
\text { ściowe do takiej analizy, nie- } \\
\text { stety techniki ilościowe są nie- } \\
\text { zwykle rzadko stosowane. }\end{array}$ & $\begin{array}{l}\text { Proste metody identyfikacji zagrożeń i wa- } \\
\text { riantowe przygotowanie planów działania } \\
\text { (pesymistyczny, optymistyczny, najbar- } \\
\text { dziej prawdopodobny). Taka prosta analiza } \\
\text { jest możliwa również w przypadku naj- } \\
\text { mniejszych przedsiębiorstw. }\end{array}$ \\
\hline $\begin{array}{l}\text { Bariery mikroekono- } \\
\text { miczne/wewnętrzne }\end{array}$ & $\begin{array}{l}\text { Niedostrzeganie potrzeb ana- } \\
\text { lizy wewnętrznej przedsię- } \\
\text { biorstwa, wykorzystywania } \\
\text { narzędzi wspomagających za- } \\
\text { rządzanie, brak wiedzy na te- } \\
\text { mat takich narzędzi }\end{array}$ & $\begin{array}{l}\text { Wykorzystanie najprostszych rachunków } \\
\text { ekonomicznych do oceny efektywności go- } \\
\text { spodarowania, np. proste metody kalkulacji } \\
\text { cen, analiza progu rentowności, analiza } \\
\text { kosztów w oparciu prowadzoną ewidencję } \\
\text { i rachunek kosztów. W przypadku średnich } \\
\text { przedsiębiorstw możliwe jest stosowanie } \\
\text { decyzyjnych rachunków kosztów, budżeto- } \\
\text { wania, czy rachunku odpowiedzialności. } \\
\text { Z technik finansowych - również te które } \\
\text { wykorzystują wartość pieniądza w czasie. }\end{array}$ \\
\hline
\end{tabular}

Źródło: opracowanie własne na podstawie studiów literatury: m.in. M. Bednarczyk, Otoczenie i przedsiębiorczość w zarządzaniu strategicznym organizacja gospodarcza. Zeszyty Naukowe. Monografie nr 128, Kraków 1996; N.C. Churchil, V.L. Levis, The five stages of small business growth, Harvard Business Review, May-June 1983; A. Kaszuba-Perz, Warunki przezwyciężania barier rozwoju matych I średnich przedsiębiorstw w Polsce południowo-wschodniej, rozprawa doktorska-UEK, Kraków 2001, materiał niepublikowany; M. Kochmańska, Bariery rozwoju przedsiębiorczości matych i średnich firm, Zeszyty Naukowe 1, Sosnowiec 2007; M. Matejun, Bariery rozwoju matych i średnich przedsiębiorstw (na podstawie badań w aglomeracji tódzkiej) [w:] Przedsiębiorczość szansa na sukces rzadu, gospodarki, przedsiębiorstw, społeczeństwa, red. K. Piech, M. Kulikowski, Warszawa 2003; R. Lisowska, Analiza warunków ograniczających rozwój matych i średnich przedsiębiorstw funkcjonujacych w regionach zmarginalizowanych [w:] Wyzwania i perspektywy zarzadzania w matych i średnich przedsiębiorstwach, red. M. Matejun, Warszawa 2010.

Różnorodność czynników wpływających na sposoby i modele zarządzania w kolejnych fazach wzrostu przedsiębiorstwa skłania do rozważań o tym, które spośród instrumentów wspomagających procesy decyzyjne, w tym zwłaszcza narzędzi rachunkowości zarządczej, mogłyby być przydatne w przełamywaniu trudności pojawiających się w okresach przełomowych w cyklu życia małej i średniej firmy (zob. tab.2). W kolejnych fazach życia przedsiębiorstwa - nastawienie samego przedsiębiorcy, jego skłonność do poszukiwania nowych metod działania (również w obszarze zarządzania firmą), a przede wszystkim jego rola w organizacji - ulegają zmianom. Są to tylko nieliczne czynniki wpływające na zmiany 
w strukturze organizacyjnej i sposobach zarządzania. Średnie przedsiębiorstwa z kolei często uważane za doświadczone, a nawet dojrzałe, wykazują permanentne zainteresowanie nowatorskimi narzędziami wspomagającymi procesy decyzyjne ${ }^{14}$.

Tabela 2. Proponowane narzędzia rachunkowości zarządczej wspomagające pokonanie kryzysów i barier w procesie wzrostu małego i średniego przedsiębiorstwa

\begin{tabular}{|c|c|c|c|}
\hline $\begin{array}{c}\text { Kryzysy/przełomy pojawia- } \\
\text { jące się pomiędzy kolejnymi } \\
\text { etapami wzrostu przedsię- } \\
\text { biorstwa } \\
\end{array}$ & $\begin{array}{c}\text { Identyfikacja trudności } \\
\text { lub/i potrzeby informa- } \\
\text { cyjne }\end{array}$ & $\begin{array}{c}\text { Wybrane narzędzia } \\
\text { rachunkowości za- } \\
\text { rządczej }\end{array}$ & $\begin{array}{l}\text { Pozostałe uwagi } \\
\text { i postulaty }\end{array}$ \\
\hline Kryzys po fazie powstania & $\begin{array}{l}\text { Etap rozpoczęcia działalno- } \\
\text { ści wydaje się najtrudniej- } \\
\text { szy, stąd duża różnorodność } \\
\text { zagrożeń, są nimi m.in.: } \\
\text { - niedostrzeganie ryzyk } \\
\text { i trudności wynikających } \\
\text { z dużej konkurencyjności } \\
\text { na rynku (w sektorze, } \\
\text { branży); } \\
\text { - zbyt niskie zaangażowa- } \\
\text { nie kapitałowe/ lub zbyt } \\
\text { duże zadłużenie; } \\
\text { - często zbyt optymistyczne } \\
\text { podejście i skłonność do } \\
\text { wysokiego ryzyka. }\end{array}$ & $\begin{array}{l}\text { Wykorzystanie naj- } \\
\text { prostszych rachunków } \\
\text { ekonomicznych do } \\
\text { oceny efektywności } \\
\text { gospodarowania, np. } \\
\text { proste metody kalku- } \\
\text { lacji cen, analiza } \\
\text { progu rentowności, } \\
\text { przygotowanie biz- } \\
\text { nes-planu. }\end{array}$ & $\begin{array}{l}\text { Analiza otoczenia dla } \\
\text { lepszego zidentyfikowa- } \\
\text { nia szans i zagrożeń dla } \\
\text { dalszego funkcjonowa- } \\
\text { nia i rozwoju formy. }\end{array}$ \\
\hline Kryzys po fazie przetrwania & $\begin{array}{l}\text { Bariery do pokonania to } \\
\text { najczęściej: } \\
\text { - dostosowanie oferty do re- } \\
\text { alnych potrzeb rynku - na } \\
\text { podstawie doświadczeń } \\
\text { fazy wcześniejszej; w tym } \\
\text { wprowadzenie różnorod- } \\
\text { ności asortymentowej; } \\
\text { - błędy w zakresie marke- } \\
\text { tingu i promocji; } \\
\text { - niedostateczne kwalifika- } \\
\text { cje pracowników dla pod- } \\
\text { jęcia nowych wyzwań sto- } \\
\text { jących przed przedsiębior- } \\
\text { stwem; } \\
\text { - niedostosowanie mocy } \\
\text { produkcyjnych do wyni- } \\
\text { kających z doświadczenia } \\
\text { i popytu - potrzeb }\end{array}$ & $\begin{array}{l}\text { - Wykorzystanie ra- } \\
\text { chunków ekonomicz- } \\
\text { nych do oceny dzia- } \\
\text { łalności i podejmowa- } \\
\text { nych aktywności pro- } \\
\text { wadzących do suk- } \\
\text { cesu. } \\
\text { - Wykorzystanie ana- } \\
\text { lizy kosztów utraco- } \\
\text { nych korzyści }\end{array}$ & $\begin{array}{l}\text { Poprzez zmiany } \\
\text { w strukturze organiza- } \\
\text { cyjnej, możliwe jest za- } \\
\text { stosowanie nowych spo- } \\
\text { sobów i metod działa- } \\
\text { nia, zwłaszcza że po } \\
\text { etapie przetrwania } \\
\text { zmienia się sposób za- } \\
\text { rządzania na pośredni, } \\
\text { więc pojawia się średni } \\
\text { szczebel. }\end{array}$ \\
\hline
\end{tabular}

${ }^{14}$ Szerzej zob. A. Kaszuba-Perz, Wzrost matych i średnich przedsiębiorstw w kontekście stosowanych narzędzi rachunkowości zarządczej i controllingu, Nierówności Społeczne a Wzrost Gospodarczy, z. 20, red. nauk. M.G. Woźniak, Rzeszów 2011; A. Kaszuba-Perz, Wybrane uwarunkowania ksztattujące skłonność przedsiębiorstw do stosowania narzędzi rachunkowości zarządczej w kolejnych etapach ich rozwoju, Zeszyty Naukowe Politechniki Rzeszowskiej, ,Modern Management Review" 2/2014. 


\begin{tabular}{|c|c|c|c|}
\hline $\begin{array}{l}\text { Kryzys po fazie sukcesu } \\
\text { przez wydzielanie/ } \\
\text { Kryzys po fazie sukcesu } \\
\text { przez wzrost }\end{array}$ & $\begin{array}{l}\text { Trudności mogą wystąpić } \\
\text { m.in.: } \\
\text { - w obszarze zarządzania } \\
\text { zaopatrzeniem i produkcją, } \\
\text { na skutek zmiany rozmia- } \\
\text { rów działalności; } \\
\text { - w obszarze zarządzania } \\
\text { kadrami, wynikające ze } \\
\text { zmian w strukturze organi- } \\
\text { zacyjnej i większej niż do- } \\
\text { tychczas formalizacji prze- } \\
\text { pływu informacji; } \\
\text { - w obszarze sprzedaży, na } \\
\text { skutek dużej różnorodności } \\
\text { w ofercie, a w ślad za tym } \\
\text { trudności w analizowaniu } \\
\text { rentowności poszczegól- } \\
\text { nych asortymentów }\end{array}$ & $\begin{array}{l}\text { - Zastosowanie } \\
\text { zwłaszcza decyzyj- } \\
\text { nych rachunków kosz- } \\
\text { tów dla trafniejszej } \\
\text { kalkulacji kosztów na } \\
\text { potrzeby podejmowa- } \\
\text { nia decyzji cenowych. } \\
\text { - Zastosowanie narzę- } \\
\text { dzi badających ren- } \\
\text { towność poszczegól- } \\
\text { nych asortymentów. }\end{array}$ & $\begin{array}{l}\text { - Zastosowanie narzę- } \\
\text { dzi zarządzania ka- } \\
\text { drami, dla poprawy } \\
\text { sprawności przepływu } \\
\text { informacji. } \\
\text { - Zastosowanie nowo- } \\
\text { czesnych metod zarzą- } \\
\text { dzanie produkcja i zapa- } \\
\text { sami (np. Lean, Just In } \\
\text { time itd.) }\end{array}$ \\
\hline Kryzys po fazie rozwoju & $\begin{array}{l}\text { - braki w wykwalifikowa- } \\
\text { nej kadrze; } \\
\text { - niechęć pracowników we } \\
\text { wprowadzaniu nowych roz- } \\
\text { wiązań } \\
\text { - złe zarządzanie kapitałem }\end{array}$ & $\begin{array}{l}\text { Zwłaszcza w momen- } \\
\text { cie tego przełomu nie- } \\
\text { zbędne jest wsparcie } \\
\text { decyzji profesjonal- } \\
\text { nymi narzędziami: } \\
\text { - Mogą to być zinte- } \\
\text { growane informa- } \\
\text { tyczne systemy wspo- } \\
\text { magające zarządzanie } \\
\text { (w przypadku posia- } \\
\text { danych zasobów fi- } \\
\text { nansowych na ich } \\
\text { wdrożenie) } \\
\text { - Mogą to być rów- } \\
\text { nież metody badania } \\
\text { efektywności podej- } \\
\text { mowanych aktywno- } \\
\text { ści inwestycyjnych }\end{array}$ & $\begin{array}{l}\text { Przyjmując jako główną } \\
\text { strategię - ustawiczny, } \\
\text { zrównoważony wzrost, } \\
\text { należy wdrażać innowa- } \\
\text { cyjne rozwiązania } \\
\text { w każdej dziedzinie } \\
\text { funkcjonowania pod- } \\
\text { miotu: począwszy od } \\
\text { zarządzania kadrą, po- } \\
\text { przez badania nad no- } \\
\text { wymi produktami, skoń- } \\
\text { czywszy na narzędziach } \\
\text { finansowo-controllingo- } \\
\text { wych. }\end{array}$ \\
\hline $\begin{array}{l}\text { Faza dojrzałości - możliwe } \\
\text { do wystąpienia kryzysy }\end{array}$ & $\begin{array}{l}\text { W tej fazie najczęściej poja- } \\
\text { wiającą się barierą jest nie- } \\
\text { chęć do zmian. Świadomość } \\
\text { osób zarządzających firmą, } \\
\text { często ogranicza się do } \\
\text { utrzymania stabilizacji w } \\
\text { poczuciu osiągniętych do- } \\
\text { tychczas sukcesów. Zmniej- } \\
\text { sza się skłonność do podej- } \\
\text { mowania aktywności ryzy- } \\
\text { kownych. W przypadku } \\
\text { firm rodzinnych na tym eta- } \\
\text { pie pojawia się często pro- } \\
\text { blem sukcesji. }\end{array}$ & $\begin{array}{l}\text { - Instrumenty analizy } \\
\text { wartości firmy. } \\
\text { - Innowacyjne narzę- } \\
\text { dzia zarządzania zaso- } \\
\text { bami ludzkimi, przy } \\
\text { pomocy np. zrówno- } \\
\text { ważonej karty wyni- } \\
\text { ków. } \\
\text { - Wybrane nowocze- } \\
\text { sne rachunki kosztów } \\
\text { np. Target Costing, } \\
\text { Kaizen Costing i inne } \\
\text { - Wykorzystanie kon- } \\
\text { cepcji rachunkowości } \\
\text { behawioralnej }\end{array}$ & $\begin{array}{l}\text { Dla podtrzymania roz- } \\
\text { woju, należy przede } \\
\text { wszystkim wprowadzać } \\
\text { instrumenty wspierające } \\
\text { zarządzanie kapitałem } \\
\text { intelektualnym. } \\
\text { Sprawne zarządzanie } \\
\text { kadrami, z naciskiem na } \\
\text { ustawiczny rozwój } \\
\text { może przyczynić się do } \\
\text { przełamania trudności w } \\
\text { tym etapie życia przed- } \\
\text { siębiorstwa. }\end{array}$ \\
\hline
\end{tabular}

Źródło: opracowanie własne na podstawie studiów literatury: m.in. M. Bednarczyk, Otoczenie i przedsiębiorczość...; N.C. Churchil, V.L. Levis, The five stages...; A. Kaszuba-Perz, Warunki przezwyciężania barier...; M. Kochmańska, Bariery rozwoju...; M. Matejun, Bariery rozwoju matych i średnich...; R. Lisowska, Analiza warunków... 
Biorąc pod uwagę tylko niektóre determinanty kształtujące tempo, zakres i rodzaj zmian zachodzących w rozwijających się przedsiębiorstwach, należy podkreślić dużą różnorodność przebiegu procesów wzrostu (tzn. indywidualny ich charakter) wynikającą ze specyfiki przedsiębiorstwa, branży oraz indywidualnych cech przedsiębiorcy i jego współpracowników. Oczywiście tego rodzaju odmienności wpływających na indywidualny rozwój przedsiębiorstwa jest wiele, w opracowaniu zostały wymienione tylko wybrane, zwłaszcza te które implikują zastosowanie ilościowych metod wspomagających zarządzanie. Należy zatem podkreślić fakt, iż narzędzia rachunkowości zarządczej wraz z rachunkiem ekonomicznym, a także analiza finansowa, mogą być wykorzystywane w pokonywaniu barier i kryzysów, zgodnie z indywidualnymi cechami i przedsiębiorstwa.

Warto również podkreślić, iż zastosowanie najprostszych narzędzi analizy i diagnozy sytuacji przedsiębiorstwa, chociażby niektórych spośród wskazanych w tab. 1, nie zawsze wymaga ponoszenia wysokich nakładów finansowych, lecz jedynie wiedzy i zaangażowania samego przedsiębiorcy. Dotyczy to zwłaszcza rachunków kosztów.

\section{PODSUMOWANIE}

Proces likwidacji barier rozwoju małych i średnich przedsiębiorstw wymaga wysiłku instytucji i władz w ich otoczeniu, lecz przede wszystkim zaangażowania i aktywności samych przedsiębiorców. Ważnym problemem są jednak przeszkody tkwiące w działaniach właścicieli firm, związane z ich postawą. Rodzaj, wielkość i zakres trudności - są uzależnione od wielu czynników, w tym również od wieku przedsiębiorstwa. Stąd ważne wydaje się właściwe dobranie instrumentów, które będą pomagały w ich pokonaniu. Jak piszą D. Dobija i M. Kucharczyk, dla właściwego zarządzania wartością firmy (a jej budowanie jest przecież celem każdego przedsiębiorcy), duże znaczenie mają nowoczesne narzędzia ograniczające ryzyko działalności i wspierające efektywny wzrost organizacji ${ }^{15}$. Wydaje się, że w przypadku grupy małych i średnich przedsiębiorstw, dużego znaczenia nabiera nawet najprostszy rachunek ekonomiczny, bazujący na analizie, kontroli, prognozie i kalkulacji kosztów. Rachunek taki nie musi posiadać znamion zintegrowanych systemów jakimi dysponują duże przedsiębiorstwa, a jego wdrożenie może bazować przede wszystkim na wiedzy i zaangażowaniu przedsiębiorcy i jego współpracowników. Tym samym zastosowanie prostych narzędzi rachunkowości zarządczej w ramach takiego rachunku ekonomicznego, nie będzie wymagać ponoszenia tak wysokich nakładów inwestycyjnych, jak w przypadku zintegrowanych systemów wspomagających zarządzanie.

\section{LITERATURA}

[1] Bednarczyk M., Otoczenie i przedsiębiorczość w zarządzaniu strategicznym organizacja gospodarcza. Zeszyty Naukowe. Monografie nr 128, Wydawnictwo Akademii Ekonomicznej w Krakowie, Kraków 1996.

[2] Bober P., Chęciński S., Kryzys gospodarczy a rozwój sektora matych i średnich przedsiębiorstw w Polsce, Zeszyty Naukowe Uniwersytetu Szczecińskiego nr 690; Finanse, Rynki Finansowe, Ubezpieczenia nr 51/2012.

[3] Borowiecki R., Siuta-Tokarska B., Problemy funkcjonowania matych i średnich przedsiębiorstw w Polsce, Difin, Warszawa 2008.

15 D. Dobija, M. Kucharczyk (red.), Rachunkowość zarządcza. Analiza i interpretacja, Warszawa 2014. 
[4] Dobija D., Kucharczyk M. (red.), Rachunkowość zarzadcza. Analiza i interpretacja, Oficyna Wolters Kluwer business, Warszawa 2014.

[5] Churchil N.C., Levis V.L., The five stages of small business growth, Harvard Business Review, May-June 1983.

[6] Gorzelany-Dziadkowiec M., Kozień E., Wptyw kryzysu na rozwój małego przedsiębiorstwa, w: Zeszyty Naukowe UEK, 2013/ 908.

[7] Greiner L.E., Evolution and Revolution as Organizations Grow, „Harvard Business Review”, July-August 1972.

[8] Kaszuba-Perz A., Warunki przezwyciężania barier rozwoju małych i średnich przedsiębiorstw w Polsce potudniowo-wschodniej, rozprawa doktorska - UEK, Kraków 2001, materiał niepublikowany.

[9] Kaszuba-Perz A., Wzrost matych i średnich przedsiębiorstw w kontekście stosowanych narzędzi rachunkowości zarządczej i controllingu, Nierówności Społeczne a Wzrost Gospodarczy, z. 20, red. nauk. M.G. Woźniak, Wydawnictwo UR, Rzeszów 2011.

[10] Kaszuba-Perz A., Wybrane uwarunkowania ksztattujące sktonność przedsiębiorstw do stosowania narzędzi rachunkowości zarzadczej w kolejnych etapach ich rozwoju, Zeszyty Naukowe Politechniki Rzeszowskiej, „Modern Management Review” 2/2014.

[11] Kochamńska M., Bariery rozwoju przedsiębiorczości małych i średnich firm, Zeszyty Naukowe 1, Wydawnictwo Wyższej Szkoły Humanitas, Sosnowiec 2007.

[12] Lisowska R., Analiza warunków ograniczających rozwój matych i średnich przedsiębiorstw funkcjonujacych $w$ regionach zmarginalizowanych [w:] Wyzwania i perspektywy zarządzania $w$ małych i średnich przedsiębiorstwach, red. M. Matejun, Wydawnictwo C.H. Beck, Warszawa 2010.

[13] Lisowska R., Ropega J., Przyczyny upadku matych firm na terenach zmarginalizowanych [w:] Problemy ekonomii, polityki ekonomicznej i finansów publicznych, red. J. Sokołowski, Wydawnictwo UE we Wrocławiu, Prace Naukowe Uniwersytetu Ekonomicznego we Wrocławiu, t. 1, nr 39/2009.

[14] Matejun M., Bariery rozwoju matych i średnich przedsiębiorstw (na podstawie badań w aglomeracji tódzkiej) [w:] Przedsiębiorczość szansą na sukces rządu, gospodarki, przedsiębiorstw, społeczeństwa, red. K. Piech, M. Kulikowski, Instytut Wiedzy SGH, Warszawa 2003.

[15] Wawrzyniak B., Odnowienie przedsiębiorstwa. Na spotkanie XXI wieku, Poltext, Warszawa 1999 .

[16] Vesper K.H., Entrepreneurship and National Policy, Carnegie-Mellon University, The Graduate School of Industrial Administration, Pittsburgh 1983.

\section{THE ROLE OF MANAGERIAL ACCOUNTING IN OVERCOMING DIFFICULTIES IN THE PROCESS OF SMALL COMPANY DEVELOPMENT}

Small and medium-sized enterprises play a significant role in economic development. This group of enterprises differs from other entities by specific features, including way of management. Knowledge of owners - entrepreneurs in the field of business management in the case of especially small enterprises, is often insufficient, and decisions are often taken intuitively. An important problem is the obstacles inherent in the activities of business owners related to their attitude. The solutions they adopt to ensure ad hoc success or in the long-term stability of the company - are taken spontaneously - based on the use of emerging opportunities. However, it should be remembered that the type, size and range of difficulties in the functioning 
of small and medium enterprises - depend on many factors, including the age of the enterprise. Their functioning is characterized by a growth process, which usually takes place by passing through successive phases of development preceded by crises. At individual stages of company life, new challenges arise that require accurate decisions, taking risks and overcoming difficulties. Hence, it seems important to choose the right instruments that will help in overcoming them. In the article, taking into account the popular models of enterprise growth, the barriers occurring at the crucial moments of the functioning of small and medium-sized companies were analyzed and an attempt was made to systematize them. On such a background selected management accounting tools are presented that can support entrepreneurs in mitigating the negative effects of crises occurring between successive stages of enterprise growth.

Keywords: small and medium-sized enterprise, managerial accounting, development of SMEs.

DOI: 10.7862/rz.2017.hss.67

Przestano do redakcji: czerwiec $2017 r$.

Przyjęto do druku: grudzień 2017 r. 